\title{
A 54-year record of changes at Chalaati and Zopkhito glaciers, Georgian Caucasus, observed from archival maps, satellite imagery, drone survey, and ground-based investigation
}

\author{
Levan G. TIELIDZE ${ }^{1,2,3}$, David SVANADZE ${ }^{4}$, Lela GADRANI ${ }^{1,5}$, Lasha ASANIDZE ${ }^{1}$, \\ Roger D. WHEATE ${ }^{6}$ and Gordon S. HAMILTON ${ }^{5+}$
}

\begin{abstract}
Individual glacier changes are still poorly documented in the Georgian Caucasus. In this paper, the change of Chalaati and Zopkhito glaciers in Georgian Caucasus has been studied between 1960 and 2014. Glacier geometries are reconstructed from archival topographic maps, Corona and Landsat images, along with modern field surveys. For the first time in the Georgian Caucasus aerial photogrammetric survey of both glacier termini was performed (2014) using a drone or Unmanned Aerial Vehicle, where high-resolution orthomosaics and digital elevation models were produced. We show that both glaciers have experienced area loss since 1960: 16.2 \pm 4.9 per cent for Chalaati Glacier and 14.6 \pm 5.1 per cent for Zopkhito Glacier with corresponding respective terminus retreat by $\sim 675 \mathrm{~m}$ and $\sim 720 \mathrm{~m}$. These were accompanied by a rise in the equilibrium line altitudes of $\sim 35 \mathrm{~m}$ and $\sim 30 \mathrm{~m}$, respectively. The glacier changes are a response to regional warming in surface air temperature over the last half century. We used a long-term temperature record from the town of Mestia and short-term meteorological observations at Chalaati and Zopkhito glaciers to estimate a longer-term air temperature record for both glaciers. This analysis suggests an increase in the duration of the melt season over the 54-year period, indicating the importance of summertime air temperature trends in controlling glacier loss in the Georgian Caucasus. We also observed supra-glacial debris cover increase for both glaciers over the last half century: from $6.16 \pm 6.9$ per cent to $8.01 \pm 6.8$ per cent for Chalaati Glacier and from $2.80 \pm 6.3$ per cent to $8.53 \pm 5.7$ per cent for Zopkhito Glacier.
\end{abstract}

Keywords: glacier change, glacier monitoring, supra-glacial debris cover, climate change, Greater Caucasus, drone survey, Chalaati Glacier, Zopkhito Glacier

Received January 2020, Accepted May 2020.

\section{Introduction}

Climate change is causing nearly all of the world's mountain glaciers to lose mass (VAughan, D.G. et al. 2013) which now accounts for about one third of the cryosphere's total contribution to global sea level rise (GARdner, A.S. et al. 2013). Mountain glaciers also play an important role in the regional hydrological cycle by modulating the storage and release of freshwater, so as they retreat, the availability of runoff for irrigation and hydro-power generation is altered (KALTENBORN, B.P. et al. 2010) and there are potential impacts on ecosystem health (JACOBSEN, D. et al. 2012).

The most important resource provided by glaciers for Georgia is freshwater. Many rivers in the mountain regions are fed by the

\footnotetext{
${ }^{1}$ Department of Geomorphology, Vakhushti Bagrationi Institute of Geography, Ivane Javakhishvili Tbilisi State University, 6 Tamarashvili st., 0177, Tbilisi, Georgia. Correspondent author's e-mail: tielidzelevan@gmail.com

${ }^{2}$ Antarctic Research Centre, Victoria University of Wellington, PO Box 600, 6140, Wellington, New Zealand.

${ }^{3}$ School of Geography Environment and Earth Sciences, Victoria University of Wellington, PO Box 600, 6140, Wellington, New Zealand.

${ }^{4}$ Department of Geography, Faculty of Exact and Natural Sciences, Ivane Javakhishvili Tbilisi State University, 1 Chavchavadze Ave., 0128, Tbilisi, Georgia.

${ }^{5}$ Formerly at: Climate Change Institute, University of Maine, Orono, ME 04469 USA. - † deceased.

${ }^{6}$ Natural Resources and Environmental Studies, University of Northern British Columbia, 3333 University Way, Prince George, V2N 4Z9, BC, Canada.
} 
melting of glaciers and snow. The largest glaciers in the Georgian Caucasus (2014) such as Lekhziri $\left(\sim 23 \mathrm{~km}^{2}\right)$, Tsaneri $\left(\sim 12 \mathrm{~km}^{2}\right)$, and Chalaati $\left(\sim 10 \mathrm{~km}^{2}\right)$, feed the Enguri River which itself is the most important source of freshwater and hydropower in Georgia. Electricity is generated by a hydroelectric power plant and dam along the Enguri, which is the third highest concrete arch dam in the world with a height of 271.5 metres (Blatter, J. and Ingram, H.M. 2001). A continued retreat of Georgian glaciers could lead to considerable changes in glacier runoff, with implications for regional water resources. Therefore, continued monitoring of glacier behaviour across Georgia is necessary.

After the dissolution of the Soviet Union, most glaciological monitoring programs stopped in the Caucasus region and the initiation of new monitoring sites was difficult. Even though some important information on recent glacier change (mainly focused on glacier mapping) has become available for the Georgian Caucasus (Stokes, C.R. et al. 2006; LAmbrecht, A. et al. 2011; Shahgedanova, M. et al. 2014; Tielidze, L.G. 2016; Tielidze, L.G. and WheAte, R.D. 2018; Tielidze, L.G. et al. 2020), the status of individual glaciers is poorly documented. In this paper, we use the same approach as we have applied on glacier change at a regional scale (TIELIDze, L.G. and WHEATE, R.D. 2018; Tielidze, L.G. et al. 2020) along with limited drone survey and ground-based observations, such as ablation tracking, temperature observations, and terminus surveying.

The Chalaati (GLIMS ID - G042713E43130N) and Zopkhito (GLIMS ID - G043422E42884N) glaciers were chosen because modern groundbased measurements are not yet available from any other glaciers in the Georgian Caucasus. The goals of our paper are:

i) to reconstruct the dynamics of Chalaati and Zopkhito glaciers over the last half century, by estimating the length and area changes, and to compare the observed changes to those of glaciers from the northern side of the Greater Caucasus and other mountain regions (e.g. European Alps, Middle East, Western Himalaya); ii) to reconstruct the longer-term air temperature record for both glaciers in 1960-2014; to observe the length of the melt season (defined as temperatures above $0{ }^{\circ} \mathrm{C}$ ) during the same time, and to estimate the change of equilibrium line altitude (ELA);

iii) to assess the alteration of the supra-glacial debris cover for both glaciers over the last half century.

\section{Study area}

The Greater Caucasus is one of the major mountain systems in Eurasia, stretching 1,300 $\mathrm{km}$ from the Black Sea in the West to the Caspian Sea in the East. A recently published inventory lists $\sim 2,000$ glaciers with $\sim 1,200 \mathrm{~km}^{2}$ total area (Tielidze, L.G. and WheAte, R.D. 2018).

The main mountain range exerts a moderating influence on the climate of Georgia by protecting it against the penetration of cold air masses from the North. Most moisture-bearing weather systems arrive from the West having passed over the Black Sea. Orographic lifting of convergent air masses in western Georgia creates favourable conditions for snowfall at any time of the year in the high mountains. In contrast, a secondary pattern of weather systems originates in the drier continental climate to the East of the Caspian Sea. These meteorological conditions give rise to a strong West-East gradient in precipitation, reflected in annual snowfalls of several metres in the western parts of the Greater Caucasus and less than a metre in the East (JinchaRADZE, Z. 2011).

An analysis of meteorological observations collected over the period 1957-2006 shows mean annual air temperatures have increased $0.2{ }^{\circ} \mathrm{C}$ in western Georgia and $0.3^{\circ} \mathrm{C}$ in eastern Georgia (Jincharadze, Z. 2011), with spring and summer months representing the most rapid warming. There has also been a modest increase in precipitation in western Georgia. Given the observed changes in climate, there is considerable interest in understanding their net effect on glaciers on the southern slopes of the Greater Caucasus. 
The central Greater Caucasus (SvanetiRacha section) is the highest part of the main mountain range in morphometry. The relief of the Svaneti-Racha section is mainly constructed from Proterozoic and Lower Paleozoic plagiogranites, plagiogneisses, quartz diorites and crystalline slates. Lower Jurassic clay slates, schists, sandstones, aleurolites, gravelites, basal conglomerates, and quartzites stretch along the intrusives as a narrow strip in the south. The morphology of the watershed range of the central Greater Caucasus is formed as a result of modern snow-glaciers influence, intense physical weathering, excaration action of Late Pleistocene glaciers and river erosion (Tielidze, L.G. et al. 2019a, b).

We focus on two glaciers in the central part of the Greater Caucasus (Figure 1, a). Chalaati Glacier is located at the headwaters of the Enguri River, the main river for hydroelectric power generation in Georgia (Svaneti region). Zopkhito Glacier is in the Rioni River basin, approximately $60 \mathrm{~km}$ to the south-east of Chalaati Glacier (Racha region).
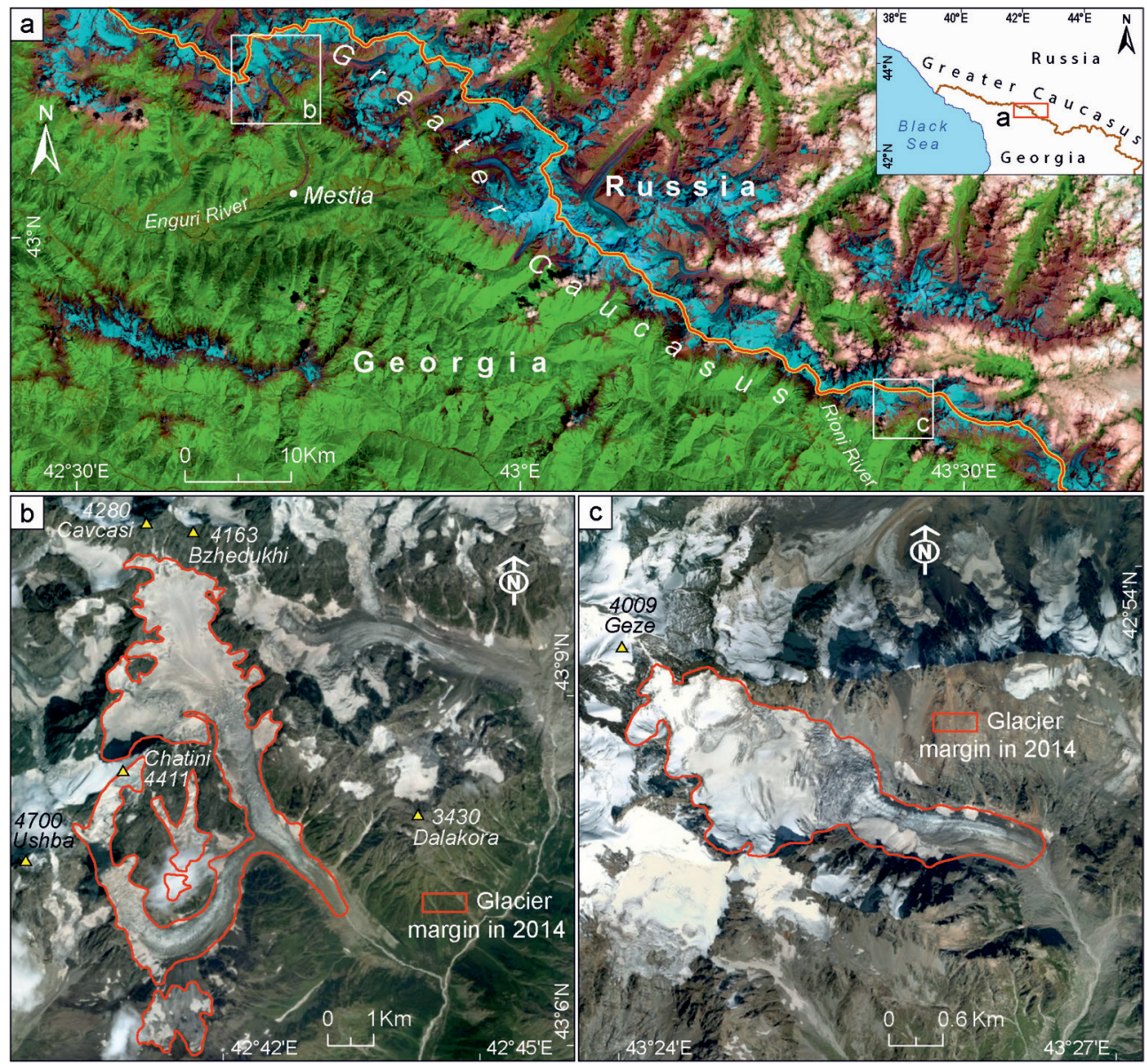

Fig. 1. Study area in the central part of the Greater Caucasus. $-\mathrm{a}=$ the location of Chalaati and Zopkhito glaciers and Mestia weather station. Blue colour corresponds to the glaciers, green to the forest zone, and brown to te bedrock. Landsat 8 OLI (03/08/2014) is used as the background; b = Chalaati Glacier; c = Zopkhito Glacier location with surrounding area in close view. Note: GeoEye (2012) are used as the background. 
Chalaati Glacier consists of two tributary glaciers which are fed by snowfall from the 4,000 m peaks: Ushba, Chatini, Cavcasi and Bzhedukhi (Figure 1, b). Its main channel (the eastern tributary) is about $6.8 \mathrm{~km}$ long, and the glacier terminus intrudes into the forest zone at an elevation of 1,960 $\mathrm{m}$ above sea level (a.s.l.), making it the lowest-elevation terminus on the southern slopes of the Greater Caucasus. The glacier has a total surface area of $10.73 \pm 0.53 \mathrm{~km}^{2}$ and its lower reaches are covered by $\sim 0.1-0.3 \mathrm{~m}$ thick debris (in 2014).

Zopkhito Glacier is a simple valley glacier beginning on the south-eastern slopes of Geze peak $(4,009 \mathrm{~m}$ ) (Figure 1, c). It is $\sim 3.6$ $\mathrm{km}$ long with an area of $2.46 \pm 0.12 \mathrm{~km}^{2}$. The ice surface of the cirque sits at an elevation of approximately 3,000 $\mathrm{m}$ a.s.l., and the ice tongue ends at $2,605 \mathrm{~m}$.

\section{Data and methods}

\section{Dataset}

We seek to reconstruct the extents of Chalaati and Zopkhito glaciers using archival and modern datasets. Baseline data are from 1:50,000 military topographic maps drawn in the 1960s and co-registered by TieLidze, L.G. and Wheate, R.D. (2018).

The modern sequence of glacier terminus positions is established using cloud-free Corona (20/09/1971), Landsat 5 TM (6/08/1986), Landsat 7 ETM+ (09/09/2000), and Landsat 8 OLI (03/08/2014) images (Table 1). The images were orthorectified prior to distribution us- ing the ASTER Global Digital Elevation Model (GDEM, 17/11/2011). All images and GDEM were supplied by the US Geological Survey's Earth Resources Observation and Science (EROS) Center and downloaded using the EarthExplorer tool (http://earthexplorer.usgs. gov/). The images have been co-registered to each other using the August 2014 Landsat image as master; registration uncertainties are 1 pixel (30 m).

\section{Glacier mapping}

Landsat images have a pixel resolution of $30 \mathrm{~m}$ for the bands used in this study. To facilitate mapping the glacier boundaries, we produced a colour-composite scene for each acquisition date, using the short-wave infrared, near infrared, and blue bands. Each glacier boundary was manually digitized by a single operator. Manual digitizing by an experienced analyst is usually more accurate than automated methods for glaciers with debris cover (RAup, B.H. et al. 2007), such as Chalaati and Zopkhito. Combining the images with topographic maps allows us to estimate the variability of Chalaati and Zopkhito glaciers over four periods corresponding to 1960-1971, 1971-1986, 1986-2000, and 2000-2014.

We map the equilibrium line altitude from Landsat 8 OLI image (03/08/2014), towards the end of the ablation season in August, for comparison with equilibrium line altitude in 1960 mapped by GobejishviLI, R.G. (1995). Terminus measurements were conducted by using the glacier outlines for each date, along the ice front - perpendicular to the flow.

Table 1. Topographic maps, satellite/ortho images and digital elevation model used in this study

\begin{tabular}{|c|c|c|c|}
\hline Date & Map/Sensor & Resolution & Scene ID \\
\hline 1960 & 1:50,000 topographic map & $5 \mathrm{~m}$ & $\begin{array}{l}\text { k_38_26_v } \\
\text { k_38_39_b }\end{array}$ \\
\hline 20/09/1971 & Corona & $2 \mathrm{~m}$ & $\begin{array}{l}\text { DS1115-2154DF070_d } \\
\text { DS1115-2154DA079 }\end{array}$ \\
\hline $\begin{array}{l}06 / 08 / 1986 \\
05 / 09 / 2000 \\
03 / 08 / 2014 \\
\text { Sept. } 2014 \\
17 / 11 / 2011\end{array}$ & $\begin{array}{l}\text { Landsat } 5 \text { TM } \\
\text { Landsat } 7 \text { ETM+ } \\
\text { Landsat } 8 \text { OLI } \\
\text { Orthomosaics } \\
\text { ASTER GDEM }\end{array}$ & $\begin{array}{l}30 \mathrm{~m} \\
15 / 30 \mathrm{~m} \\
15 / 30 \mathrm{~m} \\
20 \mathrm{~cm} \\
30 \mathrm{~m}\end{array}$ & $\begin{array}{l}\text { LT51710301986218XXX02 } \\
\text { LE71710302000249SGS00 } \\
\text { LC81710302014215LGN00 } \\
\text { UAV_DJI Phantom 4_Chalaati_Zophito } \\
\text { ASTGTM2_N43E042/E043_DEM }\end{array}$ \\
\hline
\end{tabular}


Terminus measurement by Unmanned Aerial Vehicle

Using the Unmanned Aerial Vehicle (UAV) DJI Phantom 4 pro quadcopter, we performed a limited (terminus only) aerial survey (2014) of the Chalaati and Zopkhito glaciers. Flight planning for the UAV was completed in the office using mission planner software and Google Earth. The UAV was capable of operating at elevation $\sim 3,000 \mathrm{~m}$ a.s.l. Total weight including camera and battery was $1.4 \mathrm{kgs}$. The maximum flight time for the platform at $3,000 \mathrm{~m}$ a.s.l. was around $20 \mathrm{~min}$ on a single 5,870 mAh battery. Ground station control was managed by a field tablet running APM Mission Planner for Android. The maximum length of an individual flight line was 0.4 $\mathrm{km}$ from the take-off point. The UAV images were processed using the Pix4D software. A dense point cloud was generated from the sparse point cloud model. The DEMs were generated at $20 \mathrm{~cm}$ pixel resolution and RGB orthomosaics were created at $20 \mathrm{~cm}$ pixel resolution (Figure 2). The uncertainty between terminus by Landsat image (2014) and drone survey from the same year was $\pm 20 \mathrm{~m}$.

\section{Mapping of supra-glacial debris cover and uncertainty assessment}

Supra-glacial debris cover area clearly visible on the 1960s topographic map and Corona
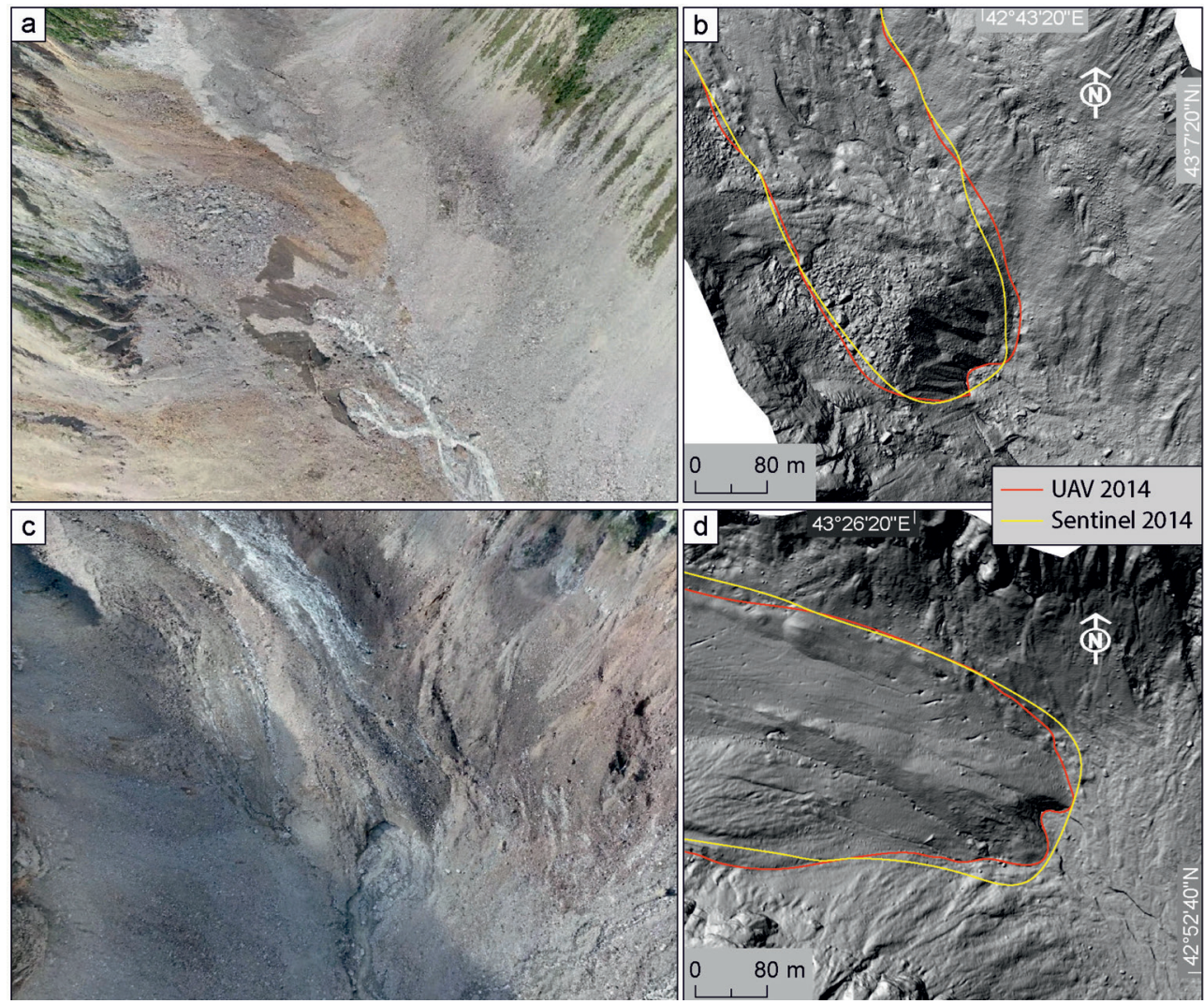

Fig. 2. An example of high resolution $(20 \mathrm{~cm}$ ) orthomosaics and hillshade (generated by $20 \mathrm{~cm}$ DEMs) for the Chalaati (a-b) and Zopkhito (c-d) glaciers. 
images from 1971 allowed us to map it manually. For the Landsat images the band ratio segmentation method (RED/SWIR; with a threshold of $\geq 2.0$ ) was used as the first step in delineating clean-ice outlines (BoLCH, T. et al. 2010; PAuL, F. et al. 2013), and then intensive manual improvements were performed (removal of misclassified areas, e.g. snow, shadows), hereafter called the semi-automated method. In the next step, similar to Tielidze, L.G. et al. (2020), supra-glacial debris cover was classified as the residual between semiautomatically derived clean-ice outlines and manually mapped glacier extent outlines. For clean ice uncertainty estimation we used a $15 \mathrm{~m}$ (1/2 pixel) buffer (Bolch, T. et al. 2010) and for debris-covered parts $60 \mathrm{~m}$ (two pixels) (Frey, H. et al. 2012). This generated an average uncertainty for the clean-ice/debris-covered areas of $4.9 \% / 6.6 \%$ for $1960,5.0 \% / 6.5 \%$ for $1971,4.7 \% / 6.4 \%$ for $1986,4.7 \% / 6.3 \%$ for 2000 , and $4.9 \% / 6.4 \%$ for 2014 . The uncertainty estimates for all Caucasus glaciers are described in previous studies (Tielidze, L.G. 2016; Tielidze, L.G. and Wheate, R.D. 2018; Tielidze, L.G. et al. 2020).

As an independent assessment of the uncertainty estimates, Zopkhito Glacier outlines from Landsat OLI 8 (03/08/14) (including clean-ice and debris-covered parts) were imported into Google Earth and manually adjusted using the available high-resolution Quickbird images (19/09/11) superimposed upon the SRTM3 topography (RAup, B.H. et al. 2014). These glacier outlines were then compared with original outlines from the Landsat 8 image (03/08/14). The area differences between the two resulting sets of outlines were \pm 5.9 per cent for supra-glacial debris cover and \pm 3.8 per cent for clean-ice. We were not able to use Google Earth software for Chalaati Glacier due to lack of cloud-free images, however, we used high-resolution GeoEye image from DigitalGlobe (ArcGlobe 10.6.1 software) as proposed by Paul, F. et al. (2013). We calculated the area uncertainty in a similar way for the Chalaati Glacier. The area differences between the two datasets were \pm 5.7 per cent for supra-glacial debris cover and \pm 3.5 per cent for clean-ice which confirms our uncertainty estimate based on the buffer method.

An additional uncertainty assessment was performed using GPS (Garmin 62stc) measurements of glacier margins ( 230 points) obtained during field investigations in 2014. The horizontal accuracy of these measurements varied from \pm 4 to $\pm 10 \mathrm{~m}$. Upper part of Figure 3 ('a' and 'b') shows the results of comparison between GPS measurements and Landsat based supra-glacial debris cover outlines. The average accuracy based on both Chalaati and Zopkhito glaciers measurements was $\pm 30 \mathrm{~m}$ for supra-glacial debris cover, hence again confirming the suitability of the selected buffer method.

\section{Ground-based investigation}

We carried out a limited amount of field work on each glacier. During a three-month period in 2011 (June-August), hourly air temperature observations were made at an elevation of 2,140 m on Chalaati Glacier using a Campbell CR21 data logger. We also tracked ablation by measuring exposed stake heights at several locations across the glacier every 7-10 days (Figure 3, c). During a brief follow-up field visit on August 16, 2014, we surveyed the terminus using global positioning system (GPS) methods.

Similar observations including the Automatic Weather Station (AWS) installation at an elevation of 2,700 $\mathrm{m}$ were carried out on Zopkhito Glacier during the months of July and August in the summers of 20072010, and August 2014 (Figure 3, d).

\section{Results and discussion}

\section{Chalaati Glacier}

Over the study period, Chalaati Glacier area decreased by $\sim 2.08 \pm 0.10 \mathrm{~km}^{2}$, equivalent to $\sim 0.04$ $\mathrm{km}^{2} / \mathrm{yr}$. Rates of area loss have been variable (Table 2 and 3$)$, with the fastest rate $\left(\sim 0.42 \% \mathrm{yr}^{-1}\right)$ occurring between 1960 and 1971. During the 

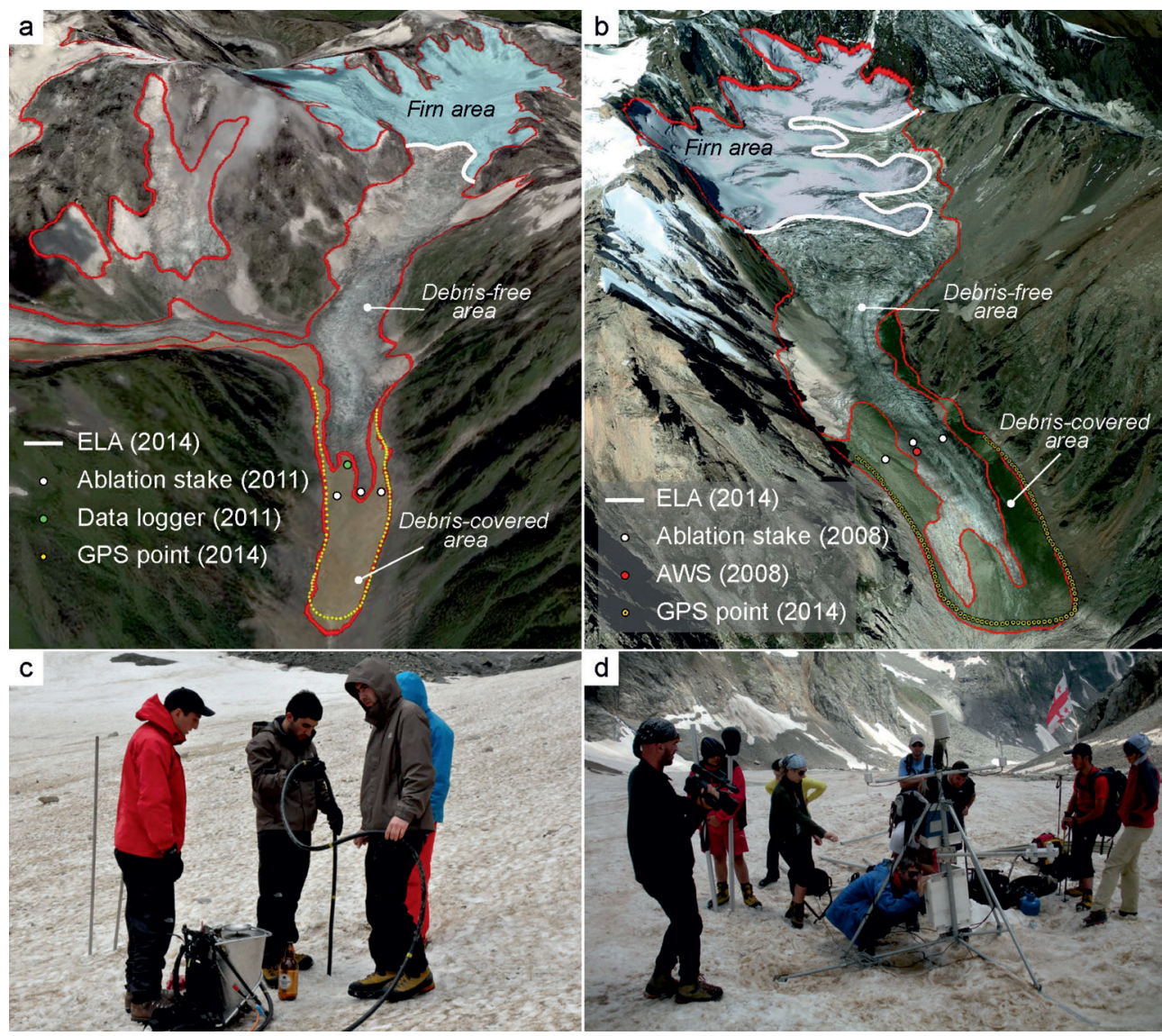

Fig. 3. Example of glacier mapping. - a = Chalaati Glacier - GeoEye (2012) image is used as the background; b = Zopkhito Glacier - Google Earth (19/09/11) image is used as the background; c = Ablation stake installation onto the Chalaati Glacier; $\mathrm{d}$ = Automatic Weather Station (AWS) installation onto the Zopkhito Glacier

next 15-year period (1971-1986), the rate of area loss was still higher $\left(\sim 0.39 \% \mathrm{yr}^{-1}\right)$. The lowest decrease rate occurred in 2000-2014 ( 0.18\% $\left.\mathrm{yr}^{-1}\right)$. In contrast to area decrease, supra-glacial debris cover area has increased from $6.16 \pm 6.9$ per cent to $8.01 \pm 6.8$ per cent over the studyperiod, mostly in 2000-2014 (Figure 4).

In addition to area changes, we also mapped linear retreat of the terminus since 1960. The fastest rates of retreat occurred during the first measurement period (1960-1971) while the lowest was measured in 1986-2000 (Table 4). This might be due to a minor $15 \mathrm{~m}$ re-advance of the terminus between 1990 and
1993 as evidenced by small terminal moraines (GobejISHVili, R.G. 1995).

The equilibrium line altitude on Chalaati Glacier was located at 3,155 m a.s.1. in 2014. The cirque extended to 3,800 $\mathrm{m}$ and covered an area of $5.01 \pm 0.25 \mathrm{~km}^{2}$. Between 1960 and 2014, the elevation of the equilibrium line rose by $\sim 35$ metres, resulting in a decrease in the accumulation zone of $\sim 0.44 \mathrm{~km}^{2}$ over the 54-year period. Using the measured areas, we calculated the accumulation-area ratio (AAR) (Table 5). Chalaati Glacier total area has decreased at a faster rate than the accumulation area, so the AAR has actually increased over the study period, although 
Table 2. Terminus position, area, and supra-glacial debris cover change since 1960 for Chalaati and Zopkhito glaciers

\begin{tabular}{c|c|c|c|c|c|c|c|c}
\hline \multirow{2}{*}{ Year } & \multicolumn{4}{|c|}{ Chalaati } & \multicolumn{4}{c}{ Zopkhito } \\
\cline { 2 - 9 } & $\begin{array}{c}\text { Terminus, } \\
\mathrm{m} \text { a.s.l. }\end{array}$ & $\begin{array}{c}\text { Total area, } \\
\mathrm{km}^{2}\end{array}$ & $\begin{array}{c}\text { Clean ice } \\
\text { area, } \mathrm{km}^{2}\end{array}$ & $\begin{array}{c}\text { Debris } \\
\text { covered } \\
\text { area, } \mathrm{km}^{2}\end{array}$ & $\begin{array}{c}\text { Terminus, } \\
\mathrm{m} \text { a.s.l. }\end{array}$ & $\begin{array}{c}\text { Total area, } \\
\mathrm{km}^{2}\end{array}$ & $\begin{array}{c}\text { Clean ice } \\
\text { area, } \mathrm{km}^{2}\end{array}$ & $\begin{array}{c}\text { Debris } \\
\text { covered } \\
\text { area, } \mathrm{km}^{2}\end{array}$ \\
\hline 1960 & 1,800 & $12.81 \pm 0.64$ & $12.02 \pm 0.59$ & $0.79 \pm 0.050$ & 2,435 & $2.88 \pm 0.14$ & $2.80 \pm 0.13$ & $0.08 \pm 0.005$ \\
1971 & 1,860 & $12.31 \pm 0.62$ & $11.51 \pm 0.57$ & $0.80 \pm 0.050$ & 2,475 & $2.81 \pm 0.14$ & $2.71 \pm 0.13$ & $0.10 \pm 0.006$ \\
1986 & 1,900 & $11.59 \pm 0.56$ & $10.81 \pm 0.51$ & $0.78 \pm 0.050$ & 2,525 & $2.72 \pm 0.13$ & $2.63 \pm 0.12$ & $0.10 \pm 0.006$ \\
2000 & 1,920 & $11.09 \pm 0.54$ & $10.34 \pm 0.49$ & $0.75 \pm 0.050$ & 2,550 & $2.64 \pm 0.13$ & $2.52 \pm 0.12$ & $0.12 \pm 0.007$ \\
2014 & 1,960 & $10.73 \pm 0.53$ & $9.87 \pm 0.48$ & $0.86 \pm 0.050$ & 2,605 & $2.46 \pm 0.12$ & $2.25 \pm 0.11$ & $0.21 \pm 0.012$ \\
\hline
\end{tabular}

Table 3. Chalaati and Zopkhito glaciers area change between 1960 and 2014

\begin{tabular}{c|c|c|c|c|c|c}
\hline \multirow{2}{*}{ Year } & \multicolumn{3}{|c|}{ Chalaati } & \multicolumn{3}{c}{ Zopkhito } \\
\cline { 2 - 6 } & $\begin{array}{c}\text { Decrease, } \\
\sim \mathrm{km}^{2}\end{array}$ & $\begin{array}{c}\text { Annual } \\
\text { decrease, } \\
\sim \mathrm{km}^{2}\end{array}$ & $\begin{array}{c}\text { Annual } \\
\text { decrease, } \\
\sim \% \mathrm{yr}^{-1}\end{array}$ & $\begin{array}{c}\text { Decrease, } \\
\sim \mathrm{km}^{2}\end{array}$ & $\begin{array}{c}\text { Annual } \\
\text { decrease, } \\
\sim \mathrm{km}^{2}\end{array}$ & $\begin{array}{c}\text { Annual } \\
\text { decrease, } \\
\sim \% \mathrm{yr}^{-1}\end{array}$ \\
\hline 1960-1971 & 0.60 & 0.05 & 0.42 & 0.07 & 0.006 & 0.22 \\
$1971-1986$ & 0.72 & 0.05 & 0.39 & 0.09 & 0.006 & 0.22 \\
$1986-2000$ & 0.50 & 0.04 & 0.30 & 0.08 & 0.005 & 0.21 \\
$2000-2014$ & 0.36 & 0.03 & 0.18 & 0.18 & 0.120 & 0.48 \\
$1960-2014$ & 2.08 & 0.04 & 0.30 & 0.42 & 0.007 & 0.28 \\
\hline
\end{tabular}

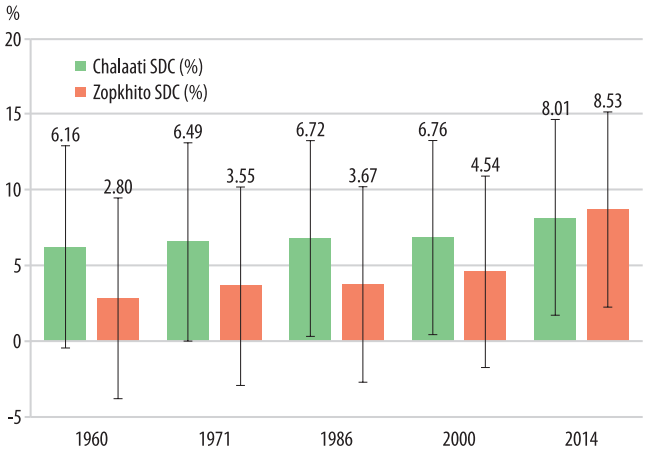

Fig. 4. Supra-glacial debris covered (SDC) area in percentage of total glacier area for Chalaati and Zopkhito glaciers between 1960 and 2014.

Table 4. Linear retreat rate of Chalaati and Zopkhito glaciers since $1960 *$

\begin{tabular}{c|c|c|c|c}
\hline \multirow{2}{*}{$\begin{array}{c}\text { Time } \\
\text { periods }\end{array}$} & \multicolumn{2}{|c|}{$\begin{array}{c}\text { Chalaati } \\
\text { Retreat of glacier } \\
\text { terminus }\end{array}$} & \multicolumn{2}{c}{$\begin{array}{c}\text { Zotreat of glacier } \\
\text { terminus }\end{array}$} \\
\cline { 2 - 5 } & $\mathrm{m}$ & $\mathrm{m} \mathrm{yr}^{-1}$ & $\mathrm{~m}$ & $\mathrm{~m} \mathrm{yr}^{-1}$ \\
\hline $1960-1971$ & 270 & 24.5 & 190 & 17.3 \\
$1971-1986$ & 135 & 9.6 & 180 & 12.0 \\
$1986-2000$ & 80 & 5.7 & 120 & 8.6 \\
$2000-2014$ & 190 & 13.6 & 230 & 16.4 \\
$1960-2014$ & 675 & 12.5 & 720 & 13.3 \\
\hline
\end{tabular}

*The average uncertainty for length change are $\pm 15 \mathrm{~m}$. the estimated uncertainty is comparable to the obtained relative changes.

The comparison of the photos of the glacier terminus in 1970 and in 2011 clearly shows the retreat of the Chalaati Glacier over the last half century (Photo 1).

\section{Zopkhito Glacier}

Over the study period, the area of Zopkhito Glacier decreased from $2.88 \pm 0.14 \mathrm{~km}^{2}$ (1960) to $2.46 \pm 0.12 \mathrm{~km}^{2}$ (2014), equivalent to a rate of $~ 0.007 \mathrm{~km}^{2} / \mathrm{yr}$. The rate of area loss was the fastest during the most recent part of the record ( $0.48 \% \mathrm{yr}^{-1}$ between 2000 and 2014) (see Table 2 and 3). Most of the area loss occurred in the ablation area of the glacier, where there was a steady retreat of the Zopkhito Glacier terminus, from 2,435 m a.s.l. (1960) to 2,605 m a.s.l. (2014). This led to a $\sim 720 \mathrm{~m}$ reduction in the length of the glacier since 1960 (see Table 4).

In contrast to total area decrease, supraglacial debris covered area increased from $2.80 \pm 6.3$ per cent to $8.53 \pm 5.7$ per cent for the Zopkhito Glacier in 1960-2014. The highest increase rate occurred in the period 20002014 (see Figure 4). 
Table 5. Accumulation-area ratio (AAR) change for Chalaati and Zopkhito glaciers between 1960 and 2014

\begin{tabular}{l|c|c|c|c|c|c}
\hline \multirow{2}{*}{ Years } & \multicolumn{2}{|c|}{ Chalaati } & \multicolumn{2}{c}{ Zopkhito } & \multicolumn{2}{c}{ AAR } \\
\cline { 2 - 7 } & $\begin{array}{c}\text { Accumulation } \\
\text { (firn) area, } \\
\mathrm{km}^{2}\end{array}$ & $\begin{array}{c}\text { Total area, } \\
\mathrm{km}^{2}\end{array}$ & $\begin{array}{c}\text { Accumulation } \\
\text { (firn) area, } \\
\mathrm{km}^{2}\end{array}$ & $\begin{array}{c}\text { Total area, } \\
\mathrm{km}^{2}\end{array}$ & Chalaati & Zopkhito \\
\hline 1960 & $5.01 \pm 0.25$ & $12.81 \pm 0.64$ & $1.69 \pm 0.08$ & $2.88 \pm 0.14$ & $0.39 \pm 0.44$ & $0.58 \pm 0.11$ \\
1971 & $4.95 \pm 0.25$ & $12.31 \pm 0.62$ & $1.66 \pm 0.08$ & $2.81 \pm 0.14$ & $0.40 \pm 0.43$ & $0.59 \pm 0.11$ \\
1986 & $4.72 \pm 0.22$ & $11.59 \pm 0.56$ & $1.61 \pm 0.07$ & $2.72 \pm 0.13$ & $0.40 \pm 0.39$ & $0.59 \pm 0.10$ \\
2000 & $4.54 \pm 0.21$ & $11.09 \pm 0.54$ & $1.60 \pm 0.07$ & $2.64 \pm 0.13$ & $0.40 \pm 0.38$ & $0.60 \pm 0.10$ \\
2014 & $4.57 \pm 0.22$ & $10.73 \pm 0.53$ & $1.38 \pm 0.06$ & $2.46 \pm 0.12$ & $0.42 \pm 0.38$ & $0.56 \pm 0.09$ \\
\hline
\end{tabular}
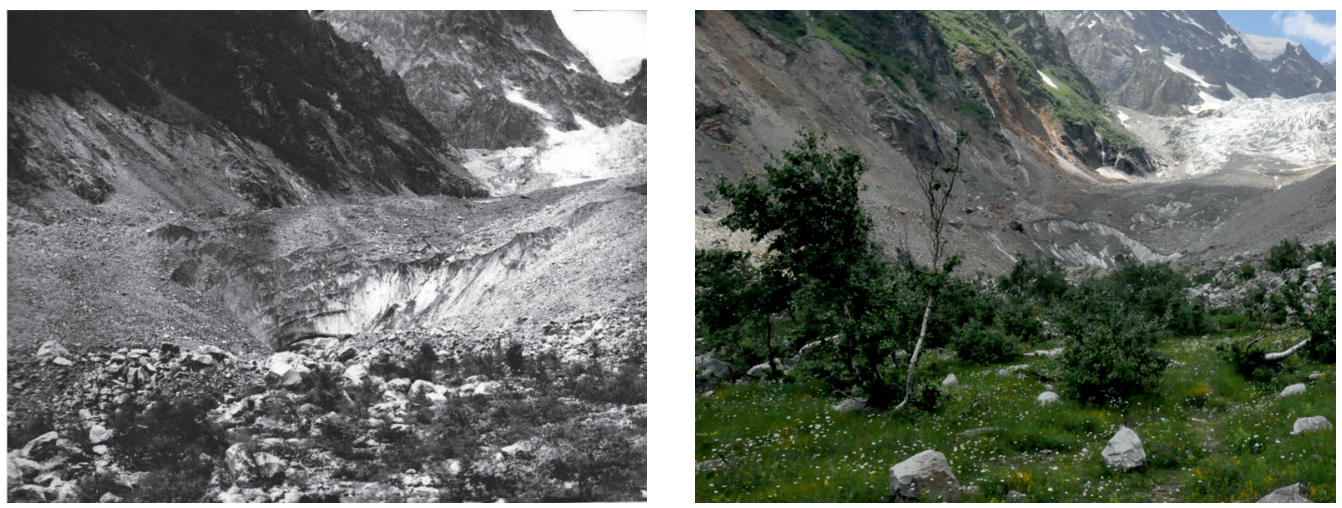

Photo 1. Chalaati Glacier terminus in 1975 (left) and in 2011 (right). Photos by Gobejishvili, R.G. (1975), and by Tielidze, L.G. (2011).

In 2014, the equilibrium line on Zopkhito Glacier was located at 3,080 $\mathrm{m}$ a.s.l. and encompassed cirque basin of an area of $1.69 \pm 0.08 \mathrm{~km}^{2}$, extending to $3,800 \mathrm{~m}$ elevation a.s.l. There was a $\sim 30 \mathrm{~m}$ rise in the elevation of the equilibrium line between 1960 and 2014, resulting in a decrease in the accumulation zone of $\sim 0.31 \mathrm{~km}^{2}$ over the 54 -year period. Using the measured areas of snow accumulation and ablation, we calculate the accumulation-area ratio (AAR) which shows that Zopkhito Glacier's total area decreased at a slightly faster rate than the accumulation area (see Table 5). We note, that this insignificant changes of the AAR remain within uncertainties, which means that AAR remained unchanged during the study-period. The comparison of the photos of the glacier ter- minus shows the change of Zopkhito Glacier over the last half century (Photo 2).

\section{Temperature}

Our study shows that both glaciers are experiencing constant retreat, except for a short period of re-advance of the Chalaati Glacier. We examine these changes in the context of regional air temperature conditions. The hourly temperature measurements only exist for occasional short (2-3 months) periods at Chalaati (summer 2011) and Zopkhito glaciers (summers 2008-2009), but detailed records are available for the weather station in the settlement of Mestia, located $\sim 7 \mathrm{~km}$ down-valley from the terminus of Chalaati 

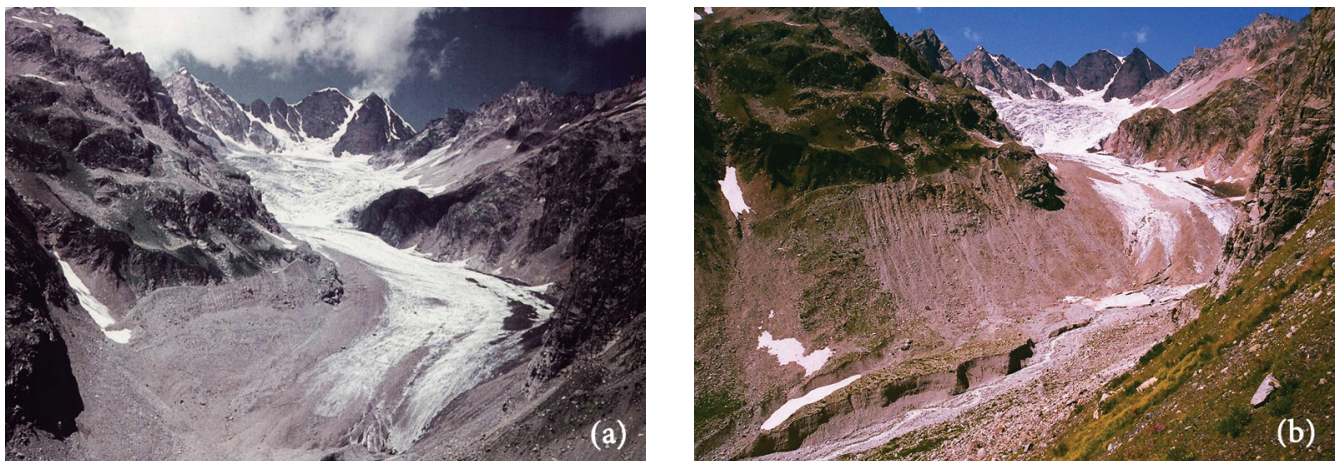

Photo 2. Zopkhito Glacier terminus in 1966 (a), and in 2010 (b). Photos by InAshvili, SH. (1966), and by Svanadze, D. (2010).

Glacier ( 60 km from Zopkhito Glacier), at an elevation of $1,440 \mathrm{~m}$ a.s.l. (see location on Figure 1). Observations are available for the period between 1960 and 2014.

The summertime hourly temperature measurements at both glaciers are in agreement with the temperature records at Mestia and enable us to compute the empirical lapse rate for the region $\left(-9.8{ }^{\circ} \mathrm{C} / \mathrm{km}\right.$ between Mestia and Chalaati, and $-7.8^{\circ} \mathrm{C} / \mathrm{km}$ between Mestia and Zopkhito). They also allow us to establish a transfer function that can extend the record of air temperatures at each glacier back to 1960. For the transfer function, we need to confirm that temperatures at both sites are well correlated. A linear regression yields a correlation coefficient of 0.89 between Mestia and Chalaati, and 0.82 between Mestia and Zopkhito (Figure 5), showing a significant correlation between both glacier records and Mestia weather station.

The estimated mean annual temperatures at both glaciers are below to the $0{ }^{\circ} \mathrm{C}$ for the entire record. Zopkhito Glacier is colder than Chalaati, as would be expected from its higher elevation terminus ( $\sim 650 \mathrm{~m}$ higher, than Chalaati). In general, the warmest temperatures occur in July (Figure 6), and the melt season (defined as temperatures above $0{ }^{\circ} \mathrm{C}$ ) lasts an average of 184 days at Chalaati and 145 days at Zopkhito. There has been an increase in the length of the melt season at both glaciers (Figure 7). The in-

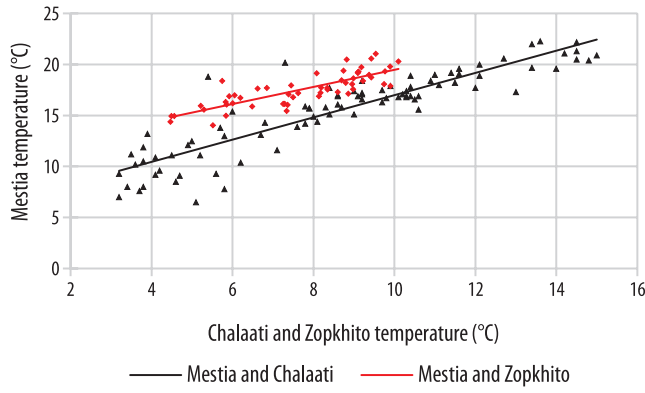

Fig. 5. Correlation between summertime hourly temperature observations at Mestia weather station $(1,440$ $\mathrm{m}$ a.s.1.) in 1960-2014, and local hourly temperatures measured at Chalaati (2,140 $\mathrm{m}$ a.s.1.), and Zopkhito

$(2,700 \mathrm{~m}$ a.s.l.) glaciers during the same time.

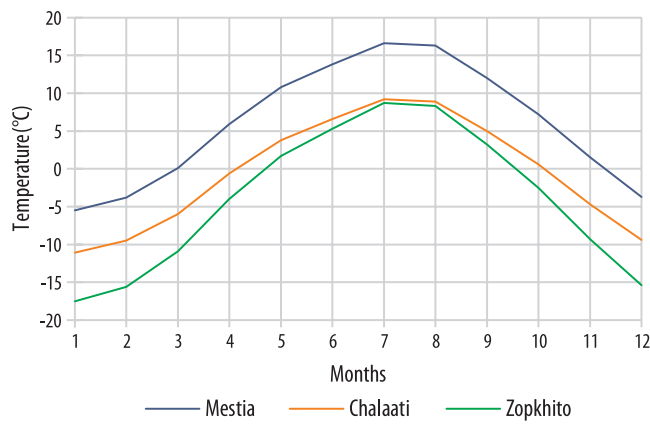

Fig. 6. Average summertime monthly air temperatures (1960-2014) at Mestia weather station (1,440 m a.s.1.), and estimated values at Chalaati (2,140 $\mathrm{m}$ a.s.1.), and Zopkhito (2,700 $\mathrm{m}$ a.s.1.) glaciers 


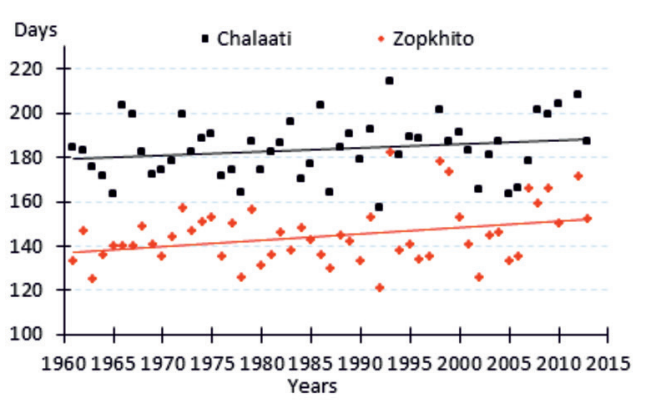

Fig. 7. Duration of melt season for Chalaati and Zopkhito glaciers in 1960-2014 and linear trends.

creasing length of the melt season is consistent with a general trend of warming air temperatures over the period 1960-2014 (Figure 8). We note that because of the very limited observation time, this has to be considered as a tentative estimate of the air temperatures at the glaciers.

\section{Equilibrium Line Altitude}

For estimating the equilibrium line altitude (ELA) it is appropriate to use at least two variables, precipitation, and temperature, which represent the effects of accumulation and ablation, respectively (OHMURA, A. et al. 1992). Often, the annual mean $0{ }^{\circ} \mathrm{C}$ isotherm is also used as the ELA (KäLLÉN, E. et al. 1979; Oer-
Lemans, J. and Van der Veen, C.J. 1984). For this purpose, we use the Mestia temperature record with calculated empirical lapse rate to estimate the height of the summer (June, July, August) $0{ }^{\circ} \mathrm{C}$ isotherm for comparison with the observed (by satellite imagery, 2014) ELA. For Chalaati Glacier, the estimated $0{ }^{\circ} \mathrm{C}$ isotherm height is 3,052 $\mathrm{m}$ a.s.l., which is $\sim 100 \mathrm{~m}$ lower than the observed ELA elevation of 3,155 $\mathrm{m}$ a.s.1. For Zopkhito Glacier, the estimated $0{ }^{\circ} \mathrm{C}$ isotherm occurs at $3,465 \mathrm{~m}$ a.s.l., which is $\sim 400 \mathrm{~m}$ higher than the observed ELA at 3,080 $\mathrm{m}$ a.s.l. Surface air temperatures are not the sole control on snow line altitude, but lacking information on regional precipitation characteristics, we are unable to fully explain the difference in equilibrium line and summertime $0{ }^{\circ} \mathrm{C}$ isotherm altitudes. However, we postulate that the respective aspect of each glacier contributes to the difference in offset between the equilibrium line altitude and the height of the $0{ }^{\circ} \mathrm{C}$ isotherm. Chalaati Glacier has a predominantly south-facing aspect, which might mean solar radiation is able to drive additional melting and raise the equilibrium line altitude to above the summertime freezing isotherm. In contrast, Zopkhito Glacier faces predominantly east and is shaded from the sun by a steep ridge, which might allow snow to survive to an altitude below the regional $0{ }^{\circ} \mathrm{C}$ isotherm height.

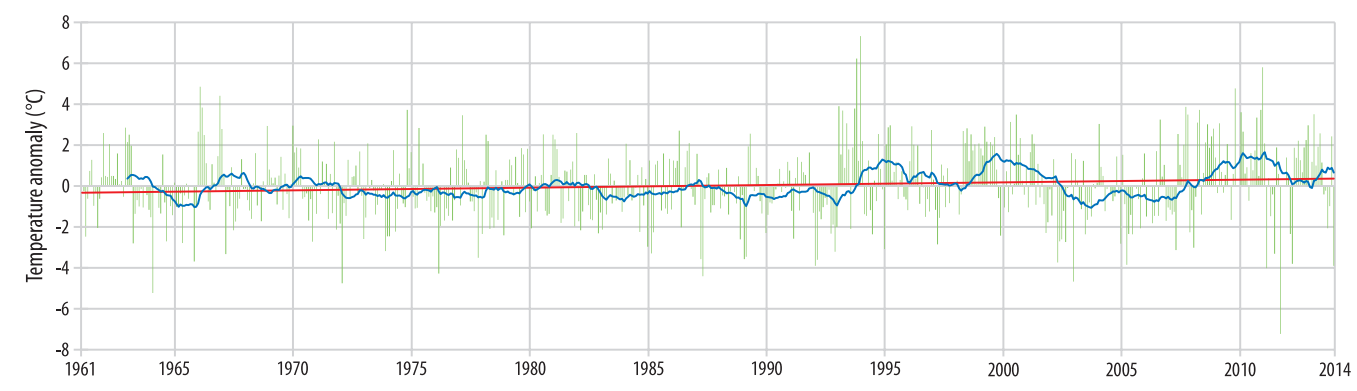

Fig. 8. Time series of monthly air temperature anomalies at Mestia weather station with respect to the 1960-2014 average. A 24 month smoothed anomaly is shown by the thick blue line. The red line is the trend showing a modest increase in warm anomalies with time. 


\section{Ablation}

Field observations at both glaciers of stake heights exposed by the ablation allow us to examine the role of air temperature on ablation. On the basis of the derived lapse rates, we can use the Mestia temperature record to produce a 'local' temperature record for each stake location and compute the cumulative positive degree days (PDD) for each site (Носк, R. 1999).

The stake observations for Chalaati Glacier were made in summer 2011 at an elevation of $2,040 \mathrm{~m}$ a.s.l. The sum of air temperatures and observed ablation in July exceed the same indicators for August. For a 27-day period from July 4 to July 31, the sum of PDDs is $298.8{ }^{\circ} \mathrm{C}$, and measured ablation was $172.5 \mathrm{~cm}$, yielding an ablation rate of $\sim 0.6$ $\mathrm{cm} /$ PDD. Over a 31-day period from July 31 until August 31, PDDs summed to $289.7^{\circ} \mathrm{C}$, and observed melting was $129.0 \mathrm{~cm}$, corresponding to an ablation rate of $\sim 0.4 \mathrm{~cm} / \mathrm{PDD}$. Repeating the analysis for Zopkhito Glacier using observations from 2008 for a stake at $2,700 \mathrm{~m}$ a.s.l. yields an ablation rate of $\sim 0.6$ $\mathrm{cm} / \mathrm{PDD}$ in July, and $\sim 0.5 \mathrm{~cm} / \mathrm{PDD}$ in August. A partial explanation for the difference in derived melt rates is solar angle, which in July is farther above the horizon than in August and, thus, supplies a greater amount of incoming radiation to melt the glacier surface.

\section{Comparison with other studies}

Direct comparisons of glacier change with previous investigations in the Greater Caucasus are difficult because most of them do not deal with individual glaciers. Therefore, our rates $\left(0.2-0.3 \% \mathrm{yr}^{-1}\right)$ are much lower than other regional studies of glacier changes in the Greater Caucasus; e.g. Tielidze, L.G. and WheAte, R.D. (2018) found generally higher rates of glacier shrinkage for south-facing glaciers during the same investigation period $\left(0.69 \% \mathrm{yr}^{-1}\right)$. This high rate can be explained by the disappearance of small glaciers $\left(<0.5 \mathrm{~km}^{2}\right)$ from the regional study by TIELIDze, L.G. and WheAte, R.D. (2018) in 1960-2014.
Comparison to Mount Ararat glaciers $\left(39.70^{\circ} \mathrm{N}, 44.30^{\circ} \mathrm{E}\right)$ in the Middle East, show that our rates are significantly higher. The glacier area of Mount Ararat has decreased from $7.98 \pm 0.80 \mathrm{~km}^{2}$ to $5.66 \pm 0.57 \mathrm{~km}^{2}$, equivalent to 29 per cent area loss (or $0.83 \% \mathrm{yr}^{-1}$ ) between 1976 and 2011 (SARIKAYA, M.A. 2012). This can partly be explained by the warm and dry climate in the Middle East versus the Greater Caucasus.

The continued existence of glaciers, like Chalaati and Zopkhito, at elevations above the summertime $0{ }^{\circ} \mathrm{C}$ isotherm altitude is probably due to their topographic setting (Grunewald, K. and Scheithauer. J. 2010) in which surrounding high peaks and steep slopes promote snow accumulation through avalanching and wind-driven processes. Little is known about accumulation and precipitation patterns in Georgian Caucasus, but any future decrease in precipitation might lead to increased rates of glacier loss as regional temperatures continue to warm.

Since the glacier snout recession is a more sensitive indicator of changes at decadal timescale than area change (BнAмBRI, R. et al. 2012; LeCLerCQ, P.W. et al. 2014), we compared Chalaati and Zopkhito glaciers cumulative length changes with other similar types of glaciers from the northern Greater Caucasus. The comparison shows that both glaciers experienced higher retreat rates than the northern counterparts (Figure 9), which is in agreement with other studies suggesting that southern facing glaciers are melting faster than northern ones (Shahgedanova, M. et al. 2014; Tielidze, L.G. and WheATe, R.D. 2018). This might be explained by relatively high radiation input in the southern slopes.

Comparison with glaciers from the European Alps shows that Greater Caucasus glaciers are retreating more steadily while the glaciers from the European Alps experience several advancing stages during the same time. Chalaati and Zopkhito glaciers' retreat was also similar in comparison with Sonapari Glacier from Western Himalaya in 1970-2000 period, while it was different in 2000-2016, when Sonapari Glacier experi- 


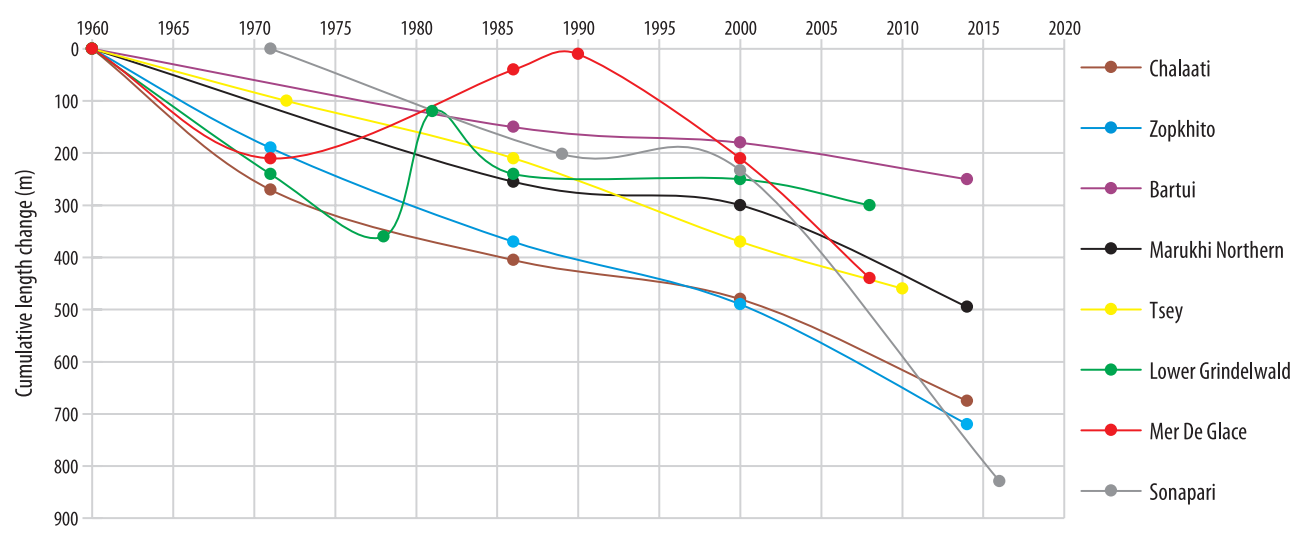

Fig. 9. Cumulative curves of glacier retreat for Chalaati and Zopkhito compared to glaciers from northern slope of the Greater Caucasus (Bartui, Marukhi Northern, Tsey - Solomina, O. et al. 2016; Tielidze, L.G. and WheAte, R.D. 2018); European Alps (Lower Grindelwald and Mer de Glace - ZumbüHL, H.J. et al. 2008); and Western Himalaya (Sonapari - MAJeEd, Z. et al. 2020).

enced its highest retreat rate $\left(\sim 37.3 \mathrm{~m} \mathrm{yr}^{-1}\right)$ (MAjeED, Z. et al. 2020) (see Figure 9). These differences can be attributed to different meteorological conditions, orographic units, and morphological types of glaciers between these mountain regions.

\section{Conclusions}

We observed a substantial loss in the area of two of the largest glaciers on the southern slope of the central Greater Caucasus, Georgia, between 1960 and 2014 based on an analysis of archival maps, modern satellite imagery, drone survey, and ground-based measurement. The main findings are as follows:

i) Chalaati Glacier lost $16.2 \pm 4.9$ per cent $\left(\sim 0.30 \% \mathrm{yr}^{-1}\right)$ of its area since 1960 , while Zopkhito Glacier lost 14.6 \pm 5.1 per cent $\left(\sim 0.27 \% \mathrm{yr}^{-1}\right)$ over the same period. A slightly greater change in area of Chalaati Glacier might be due to its terminus extending to lower elevations than Zopkhito Glacier.

ii) Chalaati Glacier experienced a terminus retreat rate of $\sim 12.5 \mathrm{~m} \mathrm{yr}^{-1}$ during the years 1960-2014 with highest retreat rate in 1960-1971 ( 24.5 $\left.\mathrm{m} \mathrm{yr}^{-1}\right)$, while the Zopkhito Glacier retreat rate was $\sim 13.3 \mathrm{~m} \mathrm{yr}^{-1}$ over the last half century, with highest rate in 1960$1971\left(\sim 17.3 \mathrm{~m} \mathrm{yr}^{-1}\right)$.

iii) The equilibrium line altitude has risen by $\sim 35$ metres for Chalaati Glacier (from 3,120 m to 3,155 m a.s.l.), and $\sim 30$ metres for Zopkhito Glacier (from 3,050 $\mathrm{m}$ to 3,080 $\mathrm{m}$ a.s.l.) resulting in a decrease in the accumulation zone for both glaciers over the 54-year period.

iv) There has been an increase in the estimated length of the melt season at both glaciers (defined as temperatures above $0{ }^{\circ} \mathrm{C}$ ) lasting an average of 184 days at Chalaati, and 145 days at Zopkhito.

v) The observed glacier loss is consistent with a $0.2{ }^{\circ} \mathrm{C}$ regional rise in near-surface annual air temperature over the last half century period as recorded at a weather station close to both glaciers. An increase in the mean summer temperature (June, July, August) appears to be a particularly important factor in glacier shrinkage, as shown by an increase in the duration of the melt season over the study period.

Glaciers on the southern slopes of the Greater Caucasus are expected to continue their retreat as regional air temperatures rise. This deglaciation will have important consequences for the management of water resources and hydropower generation in Georgia. Further work should focus on more detailed 
field observations of climatic elements, and instrumental recording of glacier processes such as ablation and supra-glacial debris cover dynamics as well as ELA definition.

Acknowledgements: The authors acknowledge the substantial contributions by co-author Hamilton, G.S. prior to his untimely death in Antarctica in 2016. We also gratefully acknowledge the support of the editor, VARGA, G. and three anonymous reviewers, for useful suggestions and comments which clearly enhanced the quality of the paper.

\section{REFERENCES}

Bhambri, R., Bolch, T. and Chaujar, R.K. 2012. Frontal recession of Gangotri Glacier, Garhwal Himalayas, from 1965-2006, measured through high resolution remote sensing data. Current Science 102. 489-494.

Blatter, J. and Ingram, H.M. (eds.) 2001. Reflections on Water: New Approaches to Transboundary Conflicts and Cooperation. Cambridge, MA, MIT Press.

Bolch, T., Menounos, B. and Wheate, R.D. 2010. Landsat-based inventory of glaciers in western Canada, 1985-2005. Remote Sensing of Environment 114. 127-137. Doi: 10.1016/j.rse.2009.08.015.

Frey, H., Paul, F. and Strozzi, T. 2012. Compilation of a glacier inventory for the western Himalayas from satellite data: methods, challenges, and results. Remote Sensing of Environment 124. 832-843.

Gardner, A.S., Moholdt, G., Cogley, J.G., Wouters, B., Arendt, A.A., Wahr, J., Berthier, E., Hock, R., Pfeffer, W.T., Kaser, G., Ligtenberg, S.R.M., Bolch, T., Sharp, M.J., Hagen, J.O., van den Broeke, M.R. and Paul, F. 2013. A reconciled estimate of glacier contributions to sea level rise: 2003 to 2009. Science 340. (6134): 852-857. Doi: 10.1126/science.1234532.

Gobejishvili, R.G. 1995. Present day glaciers of Georgia and evolution of glaciation in the mountains of Eurasia in late Pleistocene and Holocene. Thesis for a Doctor's degree. Tbilisi. (in Russian)

Grunewald, K. and Scheithauer. J. 2010. Europe's southernmost glaciers: response and adaptation to climate change. Journal of Glaciology, 56. (195): 129-143.

Носк, R. 1999. A distributed temperature-index iceand snowmelt model including potential direct solar radiation. Journal of Glaciology 45. (149): 101-111.

Jacobsen, D., Milner, A.M., Brown, L.E. and Dangles, O. 2012. Biodiversity under threat in glacier-fed river systems. Nature Climate Change 2. (5):361-364. Available at http://dx.doi.org/10.1038/nclimate1435

Jincharadze, Z. 2011. Climate Change Scenarios over South Caucasus Region. Climate Change Impact for the South Caucasus. Report to Environment and
Security Initiative. United Nations Development Programme, Vienna, UNIS.

Kaltenborn, B.P., Nellemann, C. and Vistnes, I.I. (eds.) 2010. High Mountain Glaciers and Climate Change - Challenges to Human Livelihoods and Adaptation. United Nations Environment Programme. Oslo, GRID-Arendal. Available at http://www.grida.no.

Källén, E., Crafoord, C. and Ghil, M. 1979. Free oscillation in a climate model with ice-sheet dynamics. Journal of the Atmospheric Sciences 36. (12): 2292 2303. Doi.org/10.1175/1520-0469(1979)036<2292:FO IACM>2.0.CO;2.

Lambrecht, A., Mayer, C., Hagg, W., Popovnin, V., Rezepkin, A., Lomidze, N. and Svanadze, D. 2011. A comparison of glacier melt on debris-covered glaciers in the northern and southern Caucasus. The Cryosphere 5. 525-538. Available at https://doi. org/10.5194/tc-5-525-2011

Leclerce, P.W., Oerlemans, J., Basagic, H.J., Bushueva, I., Cook, A.J. and Le Bris, R. 2014. A data set of worldwide glacier length fluctuations. The Cryosphere 8. 659-672. Doi:10.5194/tc-8-659-2014, 2014. https://doi.org/10.5194/tc-8-659-2014.

Majeed, Z., Mukhtar, M.A., Mir, R.A., Kumar, P. and KRISHNA, K. 2020. Sonapani Glacier Recession over a Century from 1906-2016, Chandra Basin, Himachal Himalaya. Journal of Geological Society of India 95. 36-44. Doi:10.1007/s12594-020-1384-5.

Oerlemans, J. and VAn der Veen, C.J. 1984. Ice Sheets and Climate. Dordrecht-Boston-Lancaster, D. Reidel Publishing Company. Doi:10.1007/978-94009-6325-2.

Ohmura, A., Kasser, P. and FunK, M. 1992. Climate at the equilibrium line of glaciers. Journal of Glaciology 38. (130): 397-411. Doi:10.3189/S0022143000002276.

Paul, F., Barrand, N.E., Baumann, S., Berthier, E., Bolch, T., Casey, K., Frey, H., Joshi, S.P., Konovalov, V., Le Bris, R., Mölg, N. Nosenko, G., Nuth, C., Pope, A., Racoviteanu, A., Rastner, P., Raup, B., Scharrer, K., StefFen, S. and Winsvold, S. 2013. On the accuracy of glacier outlines derived from remote-sensing data. Annals of Glaciology 54. 171-182. Doi: 10.3189/2013AoG63A296.

Raup, B., Kaeaeb, A., Kargel, J., Bishop, M.P., Hamilton, G.S., Lee, E., Rau, F., Paul, F., Soltesz, D., Singh Khalsa, S.J., Beedle, M. and Helm, C. 2007. Remote sensing and GIS technology in the Global Land Ice Measurements from Space (GLIMS) project. Computers and Geoscience 33 104-125.

Raup, B.H., Singh Khalsa, S.J., Armstrong, R.L., Sneed, W.A., Hamilton, G.S., Paul, F., Cawkwell, F., Beedle, M.J., Menounos, B.P., Wheate, R.D., Rott, H., Shiyin, L., XIN, L., Donghui, S., Guodong, C., Kargel, J.S., Larsen, C.F., Molnia, B.F., Kincaid, J.L., Klein, A. and Konovalov, V. 2014. Quality in the GLIMS glacier database. In Global 
Land Ice Measurements from Space. Eds.: KARgEL, J.S., Leonard, G.J., Bishop, M.P., КёÄв, A. and Raup, B.H., Berlin-Heidelberg, Springer, 163-182. Doi:10.1007/978-3-54079818-7_7.

SARIKAya, M.A. 2012. Recession of the ice cap on Mount Ararat, Turkey, from 1976 to 2011 and its climatic significance. Journal of Asian Earth Sciences 46. 190-194. Doi.org/10.1016/j.jseaes.2011.12.009

Shahgedanova, M., Nosenko, G., Kutuzov, S., Rototaeva, O. and Khromova, T. 2014. Deglaciation of the Caucasus Mountains, Russia/Georgia, in the $21^{\text {st }}$ century observed with ASTER satellite imagery and aerial photography. The Cryosphere 8 . 2367-2379. Doi:10.5194/tc-8-2367-2014.

Solomina, O., Bushueva, I., Dolgova, E., Jomelli, V., Alexandrin, M., Mikhalenko, V. and Matskovsky, V. 2016. Glacier variations in the Northern Caucasus compared to climatic reconstructions over the past millennium. Global and Planetary Change 140. (1): 28-58. Doi: 10.1016/j.gloplacha.2016.02.008.

Stokes, C.R., Gurney, S.D., Popovnin, V. and ShahgedAnova, M. 2006. Late-20 $0^{\text {th }}$-century changes in glacier extent in the Caucasus Mountains, Russia/ Georgia. Journal of Glaciology 52. (176): 99-109.

Tielidze, L.G. 2016. Glacier change over the last century, Caucasus Mountains, Georgia, observed from old topographical maps, Landsat and ASTER satellite imagery. The Cryosphere 10. 713-725. Available at https://doi.org/10.5194/tc-10-713-2016

Tielidze, L.G. and Wheate, R.D. 2018. The Greater Caucasus glacier inventory (Russia, Georgia and Azerbaijan). The Cryosphere 12. 81-94. Available at https://doi.org/10.5194/tc-12-81-2018
Tielidze, L.G., Gobejishvili, R., Maruashvili, L. and Astakhov, N. 2019a. Central Greater Caucasus. In Geomorphology of Georgia. Geography of the Physical Environment. Ed.: TIELIDze, L.G., Cham, Springer. Doi.org/10.1007/978-3-319-77764-1_9.

Tielidze, L.G., Kumladze, R.M., Wheate, R.D. and Gamkrelidze, M. 2019b. The Devdoraki Glacier catastrophes, Georgian Caucasus. Hungarian Geographical Bulletin 68. (1): 21-36. Doi: 10.15201/ hungeobull.68.1.2.

Tielidze, L.G., Bolch, T., Wheate, R.D., Kutuzov, S.S., Lavrentiev, I.I. and Zemp, M. 2020. Supra-glacial debris cover changes in the Greater Caucasus from 1986 to 2014. The Cryosphere 14. 585-598. Available at https://doi.org/10.5194/tc-14-585-2020

Vaughan, D.G., Comiso, J.C., Allison, I., Carrasco, J., Kaser, G., Kwok, R., Mote, P., Murray, T., Paul, F., Ren, J., Rignot, E., Solomina, O., Steffen, K. and Zhang, T. 2013. Observations: Cryosphere. In Climate Change 2013: The Physical Science Basis. Contribution of Working Group I to the Fifth Assessment Report of the Intergovernmental Panel on Climate Change. Eds.: Stocker, T.F., QIN, D., Plattner, G.K., Tignor, M., Allen, S.K., Boschung, J., Nauels, A., XIA, Y., BeX, V. and Midgley, P.M., Cambridge, UK, and New York, Cambridge University Press, 317-382.

Zumbühl, H.J., Steiner, D. and Nussbaumer, S.U. 2008. $19^{\text {th }}$ century glacier representations and fluctuations in the central and western European Alps: An interdisciplinary approach. Global and Planetary Change 60. (1): 42-57. Doi: 10.1016/j.gloplacha.2006.08.005. 
